\title{
The autofluorescent age pigment lipofuscin: key to age, growth and productivity of the Antarctic amphipod Waldeckia obesa (Chevreux, 1905)
}

\author{
Bodil A. Bluhm*, Thomas Brey, Michael Klages \\ Alfred-Wegener-Institut für Polar-und Meeresforschung, Columbusstrasse, 27515 Bremerhaven, Germany
}

Received 4 October 2000; received in revised form 12 January 2001; accepted 18 January 2001

\begin{abstract}
Peracarid crustaceans are among the most important taxa in terms of biodiversity and carbon-flow within the Weddell Sea benthos; however, very few data on their age, growth and productivity are available. This study uses the pigment lipofuscin as an age marker in the scavenging amphipod Waldeckia obesa (Chevreux, 1905) from the eastern Weddell Sea. Resin brain sections of 159 trap-caught specimens (1.2 to $7.7 \mathrm{~mm}$ coxal plate length $L_{\text {cox }}$ equal to 5 to $31 \mathrm{~mm}$ total length) were recorded digitally by confocal microscopy, and images were analysed. A modal progression analysis of the lipofuscin concentration-frequency distribution revealed five regularly spaced modes presumed to reflect consecutive annual age classes. Single females outside the range of mode $\mathrm{V}$ occurred, indicating maximum age of up to 8 years in females. No regular modes were obvious from the comparable length-frequency distribution of 386 individuals. Average yearly pigment accumulation was linear, and accumulation rates did not differ between sexes. The estimates of the growth parameters $L_{\infty}$ and $k$ of the von Bertalanffy growth function were $7.47 \mathrm{~mm} L_{\text {cox }}$ and 0.50 per year in females, respectively, and $6.92 \mathrm{~mm} L_{\text {cox }}$ and 0.60 per year in males, respectively. Mortality, estimated from catch curves, amounted to 0.27 per year in females and 0.43 per year in males. $P / B$ ratio, calculated from the mass specific growth rate method, was 0.38 per year for the pooled population $(0.25$ per year in females, 0.31 per year in males, 2.26 per year in juveniles). The results are discussed with regard to advantages and
\end{abstract}

\footnotetext{
* Corresponding author. Tel.: +49-471-4831-1323; fax: +49-471-4831-1349.

E-mail address: bbluhm@awi-bremerhaven.de (B.A. Bluhm).
} 
drawbacks of the methodology, and are compared with results from warmer water habitats. (C) 2001 Elsevier Science B.V. All rights reserved.

Keywords: Age determination; Amphipoda; Antarctic; Lipofuscin; Population dynamics

\section{Introduction}

Within the Antarctic benthos, crustaceans and especially peracarids are among the most important taxa in terms of biodiversity (De Broyer and Jazdzewski, 1996; Arntz et al., 1997), and carbon flow (Jarre-Teichmann et al., 1997). A faunistic inventory of many peracarid taxa has been completed recently (e.g. Amphipoda: De Broyer and Jazdzewski, 1993, 1996; Mysidacea: Brandt et al., 1998; Cumacea: Mühlenhardt-Siegel, 1999), listing $>500$ Antarctic amphipod species, $>70 \%$ of which are endemic. Data on life cycles and population dynamics, however, are still scarce. We contribute to filling this gap by investigating population dynamics of the circum-Antarctic lysianassid amphipod Waldeckia obesa (Chevreux, 1905). This species occurs regularly at relatively shallow sites, e.g. around King George Island (15-90 m) (Arnaud et al., 1986), and down to $1030 \mathrm{~m}$ in the eastern Weddell Sea (Klages, 1991). Lysianassids, forming the largest amphipod family with more than 500 species belonging to 112 genera worldwide (Barnard and Karaman, 1991), play an important role as one of the most abundant and widespread macro-invertebrate scavenger groups in the world ocean (Slattery and Oliver, 1986), degrading and distributing organic matter at the benthic-pelagic interface (Christiansen et al., 1990). They occur primarily at water temperatures below $10^{\circ} \mathrm{C}$, and are common not only in the deepest ocean basins (Hessler et al., 1978; Thurston, 1979; Smith and Baldwin, 1982; Ingram and Hessler, 1983), but also in shallow water at high latitudes (Vader, 1972; Nagata, 1986). The high number usually caught using baited traps (Ingram and Hessler, 1987; Christiansen, 1996) and their remarkable food consumption rates (Hargrave, 1985; Klages, 1991; Hargrave et al., 1995) suggest that they play an important role in benthic food webs.

A vast range of shallow-water amphipod species from lower latitudes has been investigated with regard to their life cycles and productivity (reviewed in Sainte-Marie, 1991). The conspicuous scarcity of comparable data on high latitude species is due partly to the lack of adequate ageing techniques. The remote location and inaccessibility of high latitudes, as well as a tendency for slow growth and high longevity of many polar invertebrates, often make conventional methods unfeasible (France et al., 1991; Bannister et al., 1994; Bluhm et al., in press). The lipofuscin method recently applied to decapods by Sheehy $(1989,1990 \mathrm{a}, \mathrm{b}, \mathrm{c})$, however, overcomes some of those shortcomings. It makes use of the apparently linear accumulation of the age pigment in postmitotic eukaryotic cells throughout their life span, caused by free radical induced peroxidation processes (Sheldahl and Tappel, 1974; Porta, 1991; reviewed in Terman and Brunk, 1998). The quantity of lipofuscin in certain brain areas has been shown to be a better predictor of age than size in long-lived decapods (Sheehy, 1989, 1990a,b, 1992; Sheehy et al., 1994; Belchier et al., 1998). Separating modes derived from concentration frequencies of morphological lipofuscin, presumably representing age classes, has so far 
only been attempted in decapod crustaceans (Sheehy et al., 1998; Bluhm and Brey, in press). For the first time, we apply this approach to an amphipod species to estimate maximum longevity, age distribution, growth parameters, mortality and productivity.

\section{Materials and methods}

\subsection{Sampling}

Samples were obtained during the expedition ANT XV/3 (EASIZ II, January to March 1998) of R/V "Polarstern" to the eastern Weddell Sea (Arntz and Gutt, 1999, Fig. 1) at water depths of 400 to $800 \mathrm{~m}$. Average annual temperature close to the sea floor ranges, depending on water depth, from $0.4^{\circ} \mathrm{C}$ (Circumpolar Deep Water) to $-1.88^{\circ} \mathrm{C}$ (Antarctic Surface Water), with seasonal variability generally $<0.8^{\circ} \mathrm{C}$ (Hellmer and Bersch, 1985; Fahrbach et al., 1992). Amphipods were caught with baited traps, which were deployed for approximately $48 \mathrm{~h}$ and retrieved using acoustic releasers. Mesh size was $500 \mu \mathrm{m}$ and the entrance openings measured 2- or 5-cm diameter; for details, see Mekhanikova et al. (submitted for publication). Amphipods were sorted in

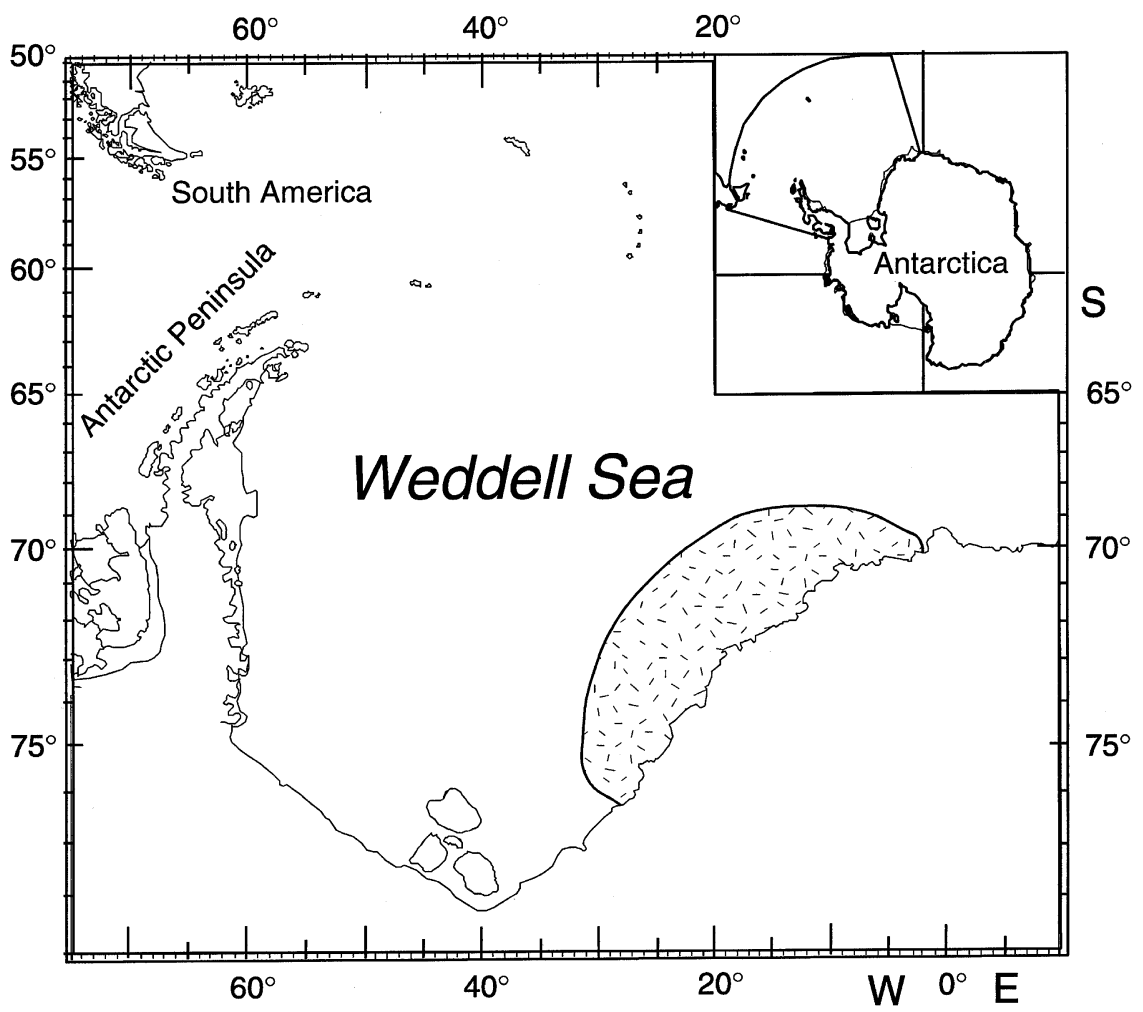

Fig. 1. Study area (hatched) in the Eastern Weddell Sea. 
the coldroom $\left(0^{\circ} \mathrm{C}\right)$ and preserved in $4 \%$ buffered formalin until embedding in spring 1999.

\subsection{Transmission electron microscopy (TEM)}

Specimens for TEM were fixed in $2.5 \%$ glutaraldehyde in $0.1 \mathrm{M}$ cacodylate buffer (pH 7.3) at $4{ }^{\circ} \mathrm{C}$ and postfixed in $0.2 \mathrm{M}$ cacodylate buffered $1 \%$ osmium tetroxide for $2 \mathrm{~h}$. Brains were dehydrated in ascending concentrations of acetone and embedded in Spurr's resin $\left(8 \mathrm{~h}\right.$ at $\left.70^{\circ} \mathrm{C}\right)$. Ultra-thin sections $(60 \mathrm{~nm})$ were stained in uranyl acetate (methanol) and Reynold's lead citrate using standard procedures and were studied with a ZEISS EM 902 TEM.

\subsection{Sample preparation for fluorescence confocal microscopy}

Body length $(L)$ of straightened formalin-preserved specimens was measured (i) as total $L\left(L_{\mathrm{t}}\right)$ from the tip of the rostrum to the end of the telson along the dorsal midline to the nearest $\mathrm{mm}$ below, and (ii) as diagonal (anterior ventral to posterior ventral) length of the fourth coxal plate $\left(L_{\text {cox }}\right)$, according to Chapelle (1995), to the nearest $0.1 \mathrm{~mm}$ below. For body size, this measure has proven to be more precise than $L_{\mathrm{t}}$ (Chapelle, 1995). Sex was determined using the second antennae, which are longer in males ( $>18$ articles) than in females ( $\leq 18$ articles), as well as the presence of oostegites in females and penial papillae in males (Walker, 1907). Specimens without oostegites or penial papillae and fewer than 18 articles were classified as juveniles. Brains were prepared for lipofuscin measurement as described for various decapod species by Sheehy (1989, 1990a), Sheehy and Wickins (1994) and Bluhm et al. (in press). After the brains were dissected, unstained, serial, horizontal $6 \mu \mathrm{m}$ resin sections were prepared following standard embedding procedures, but excluding mounting medium.

\subsection{Fluorescence confocal microscopy}

Sections were analysed with a Leica TCS NT confocal microscope at $488 \mathrm{~nm}$ excitation wavelength and a $40 \times$ oil immersion lens (numerical aperture 1.25, no zoom). In contrast to decapod brains, high density regions of lipofuscin in $W$. obesa were associated with the transition zones of anterior inferior lateral and medial somaclusters (and associated bridge), as well as the anterior superior lateral and medial somaclusters (nomenclature after MacPherson and Steele, 1980) and the respective neuropils (Fig. 2). Eight to ten approximately equidistant sections of the described areas were selected for lipofuscin analysis in each individual. Absolute values of concentrations are higher and not comparable with those published for decapod species; however, this procedure reduced the standard deviation between sections of the same individual. Digital images of $1024 \times 1024$ pixels resolution $(250 \times 250 \mu \mathrm{m}$ frame area $)$ were recorded applying Kalman averaging of four images each to reduce noise.

\subsection{Lipofuscin quantification}

Image analysis was carried out using "Image" software (National Institute of Health). The outline of the selected area was traced manually and the autofluorescent lipofuscin 


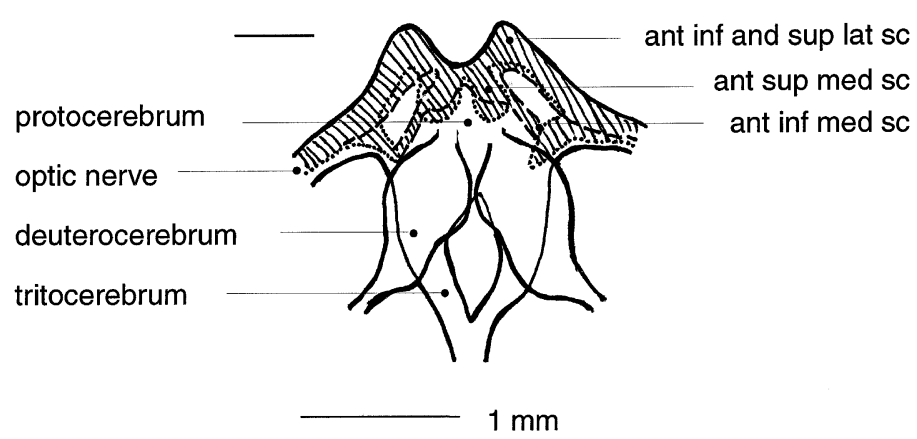

Fig. 2. W. obesa, schematic view of the brain. Hatchings mark the tissue areas used for lipofuscin quantification. The horizontal line indicates the plane of sectioning. ant: anterior, inf: inferior, lat: lateral, med: medial, sup: superior, sc: somacluster.

granules therein were discriminated using manual greyscale thresholding. The total area fraction (AF) of lipofuscin granules in the binarized selected area of the images was calculated by dividing the area of lipofuscin granules by the total area of analysed tissue and multiplying by 100 . The geometric average AF over all sections examined for each individual was calculated (which-in line with stereological convention-corresponds to volume fraction in $\%$ lipofuscin). The image analysis was performed without prior knowledge of the body length of the specimens to avoid personal bias.

\subsection{Age class identification}

A length-frequency distribution (LFD) histogram was established from the size-data $\left(L_{\mathrm{cox}}\right)$ of 386 specimens using class intervals of $0.2 \mathrm{~mm}$. A lipofuscin concentration frequency distribution (LCFD) histogram was constructed from the pigment concentration analysis of a subsample (159 specimens). For efficient comparison with the LFD, class intervals in the LCFD histogram were chosen in a way so that the main part of the data lay within a similar number of classes as in the length-frequency histogram. Potential age groups were identified by fitting normal components to modes in the LCFD histogram using the modal progression analysis routine of FiSAT (Gayanilo et al., 1996, FAO-ICLARM stock assessment tools). Within this program, Bhattacharya's method (after Bhattacharya, 1967) was applied to obtain initial values for mode means, which were refined using NORMSEP (after Hasselblad, 1966). The latter method applies the maximum likelihood concept to SEParation of the NORMally distributed components. Modes were only accepted when separated by a separation index above the critical value of 2 and when visually obvious. A Chi-square test was performed to confirm the goodness of fit of observed and predicted frequency. In the case of overlapping normal components, normal distributions were generated using the normal probability density function (Sokal and Rohlf, 1995), and individuals were designated to modes accordingly. Modes were assumed to reflect distinct broods, i.e. subsequent age classes separated by the age difference of 1 year based on observations by Chapelle (1991) on the reproductive mode of W. obesa. These modes are referred to as relative 
age (Pauly, 1984) for which we use the dimension "years +" (i) to imply that exact age depends on what time of the year the sample was taken relative to the hatching period, (ii) to account for natural spread of age in modes (the period of hatching seems to extend over a few weeks and a female releases all hatchlings within 2 or 3 days (Chapelle, personal communication; personal observation)), and (iii) to account for the fact that detectable lipofuscin accumulation may start at some point after release of hatchlings. A score of $1+$, therefore, indicates individuals between approximately 1 and 2 years of age. A yearly pigment accumulation rate was calculated from the regression of lipofuscin concentration against estimated age. Individuals used for lipofuscin analysis were not collected randomly from the available sample, but with the intention of covering the complete size range present. Hence, the age-frequency distribution (AFD) based on the lipofuscin sample is not representative for the population; however, the distribution of age within each size class is likely to be representative. A corrected AFD was established by rearranging all individuals constituting the LFD into age classes according to this information. The corrected AFD was used to compute the catch curve.

\subsection{Growth parameters}

The von Bertalanffy growth curve (VBGF):

$$
L_{a}=L_{\infty}\left(1-\mathrm{e}^{-k\left(a-a_{0}\right)}\right)
$$

and Gompertz growth curve:

$$
L_{a}=L_{\infty}\left(\mathrm{e}^{\mathrm{e}^{-k\left(a-a_{0}\right)}}\right)
$$

were fitted to the size at lipofuscin-estimated age data by the iterative nonlinear Levenberg-Marquardt algorithm (Marquardt, 1963). ( $L_{a}=$ body length at age $a$ (years), $L_{\infty}=$ asymptotic body length, $k=$ growth constant, $a_{0}=$ theoretical age at which $L_{a}=$ $0 \mathrm{~mm}$ ).

\subsection{Mortality $Z$ and productivity}

Annual mean mortality was expressed by the parameter $Z$ of the single negative-exponential mortality model (Ricker, 1979). It was estimated by linear regression as the slope (with sign changed) of the descending right arm of the catch curve, i.e. plotting the natural logarithm of the number of specimens in each age group (corrected as described above) against their corresponding (in this case lipofuscin-estimated) age. Annual $P / B$ ratio was, firstly, estimated from $Z \approx P / B$ (Allen, 1971; Brey, 1995, 1999a). Secondly, the mass-specific growth rate method (MSGRM, Crisp, 1984) was applied, which combines the information provided by the LFD, the growth function and the size-body mass relationship.

\section{Results}

\subsection{Lipofuscin characteristics}

Different types of lipofuscin-like granules were found within cells of various neuropils (e.g. Fig. 3a) and somaclusters (e.g. Fig. 3b). Considerable amounts of the 

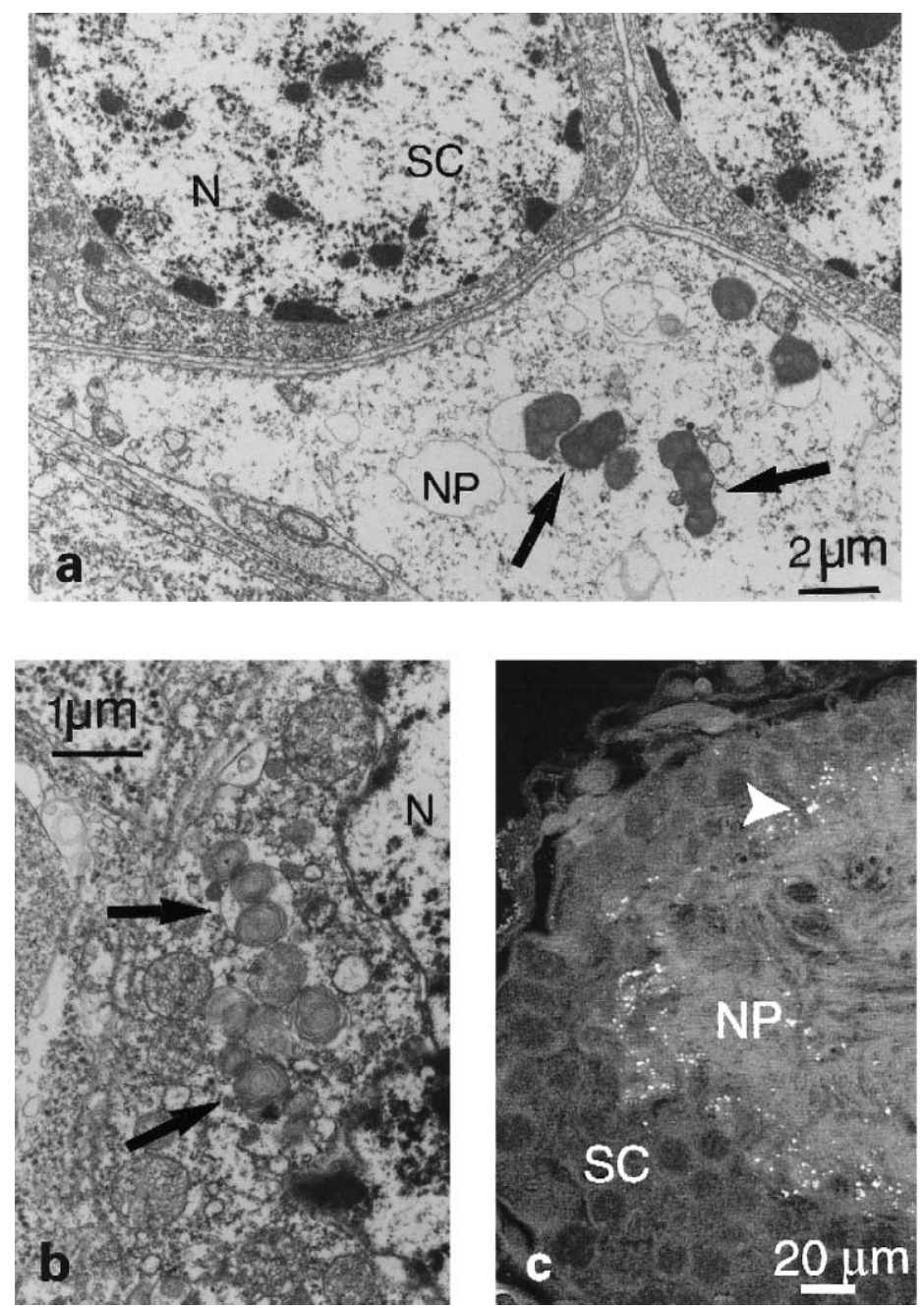

Fig. 3. Brain sections of W. obesa. (a, b) Transmission electron micrographs, (c) confocal fluorescence image. (a) Transition area between somacluster (SC) and neuropil (NP) with lipofuscin-like granules in a neuropil cell, (b) lipofuscin-like granules in a somacluster cell, (c) concentration of lipofuscin fluorescence in a distinct area between somacluster and neuropil. Examples of lipofuscin-like granules are marked with arrows. $\mathrm{N}=$ nucleus.

pigment occurred in the transition areas between somaclusters and neuropils, while granules were rare in the middle of somaclusters and neuropils, respectively. The structures in question were roundish to irregular in outline and contained variable amounts of membrane remnants of medium to high electron density embedded in granular to homogeneous material. In some cases, lipofuscin-like granules were associated with vacuoles. Granules of very high density occurred predominantly in neuropil cells. The described structures ranged in diameter from $<1 \mu \mathrm{m}$ to approximately $3 \mu \mathrm{m}$ 
and mostly occurred in groups. In the fluorescence image, they measured occasionally up to $10 \mu \mathrm{m}$, which is probably due to seemingly merged granules at lower magnification. The confocal image (Fig. 3c) shows the pigment's intense autofluorescence used for pigment quantification. As the granules in the TEM micrographs cannot be tested for their fluorescence, we refer to them as "lipofuscin-like".

\subsection{Age class identification}

A subsample of the total catch ( $n=386$ individuals) was measured and sexed (Fig. 4a). Numbers of females, males and juveniles were $157(40.7 \%), 102(26.4 \%)$ and 127 $(32.9 \%)$, respectively. The size-wet body mass (WM) relation was $\log (\mathrm{g} W \mathrm{~W})=$ $2.71 \log \left(\mathrm{mm} L_{\text {cox }}\right)-2.537\left(r^{2}=0.98, p<0.001\right)$. Body length ranged from 1.2 to $7.7 \mathrm{~mm} L_{\text {cox }}$ (5 to $31 \mathrm{~mm} L_{\mathrm{t}}$ ). The parameters $L_{\mathrm{t}}$ and $L_{\mathrm{cox}}$ were linearly related as follows: $L_{\mathrm{t}}=4.164 L_{\mathrm{cox}}+0.070\left(r^{2}=0.98, p<0.001\right)$. The LFD was characterized by two modes (Fig. 4a), the first one comprising juveniles, and the second one predominantly sexually differentiated individuals. No modes reflecting consecutive age classes were distinguishable visually and modal components could not be fitted to the distribution.

Seventy-two females, 59 males and 28 juveniles of $W$. obesa were analysed for their lipofuscin concentration as described above. Lipofuscin concentrations ranged from 0.13 $($ S.D. $=0.03)$ to $3.44($ S.D. $=0.40) \%$ area fraction $(A F)$ in females, from 0.15 (S.D. $=$ $0.05)$ to 1.90 (S.D. $=0.36) \% \mathrm{AF}$ in males and from 0 to 0.07 (S.D. $=0.04) \% \mathrm{AF}$ in juveniles. All specimens with concentrations $>2 \%$ AF $(n=10)$ were females. The standard deviation of the 8-10 analysed sections of one individual was, on average, $20 \%$ in adults and $100 \%$ in juveniles. Fitted modes were well resolved with high separation indices $(p<0.001$, Fig. 4b). Juveniles constituted mode I, and females and males modes II to V. Six females had concentrations outside the range of the fifth mode, suggesting the existence of more than five age groups. The LFCD differed from the LFD in that the former had evenly spaced modes that were clearly distinguishable by eye.

The relationship between lipofuscin content (AF) and lipofuscin-estimated age $(A)$ was highly significant (Fig. 5a, $p<0.001$ ). The linear regression equation defining the relationship was $\mathrm{AF}=0.49 A+0.49\left(r^{2}=0.95, p<0.001\right)$, corresponding to an annual lipofuscin accumulation rate of $0.49 \%$ AF. There was no significant effect of sex on lipofuscin accumulation rate (ANCOVA, $p>0.05$ ). The relation between lipofuscin concentration and size, in contrast, showed substantial scatter (Fig. 5b), especially in adults $\geq 5 \mathrm{~mm} L_{\text {cox }}$. Individuals with high lipofuscin content though, tended to be large, i.e. all specimens (except for one) of and above mode $\mathrm{V}(n=14)$ measured $\geq$ $6 \mathrm{~mm} L_{\text {cox }}$.

\subsection{Growth parameters}

The size-at-age data were modified prior to growth analysis by splitting mode I into juveniles $\leq 2.4 \mathrm{~mm} L_{\text {cox }}$ (designated age group $0+; n=14$ ) and those $>2.4 \mathrm{~mm}$ $L_{\text {cox }}$ (designated age group $1+; n=14$ ). The underlying assumption is that mode I does not represent 1 -year-old individuals if detectable lipofuscin accumulation does not start 

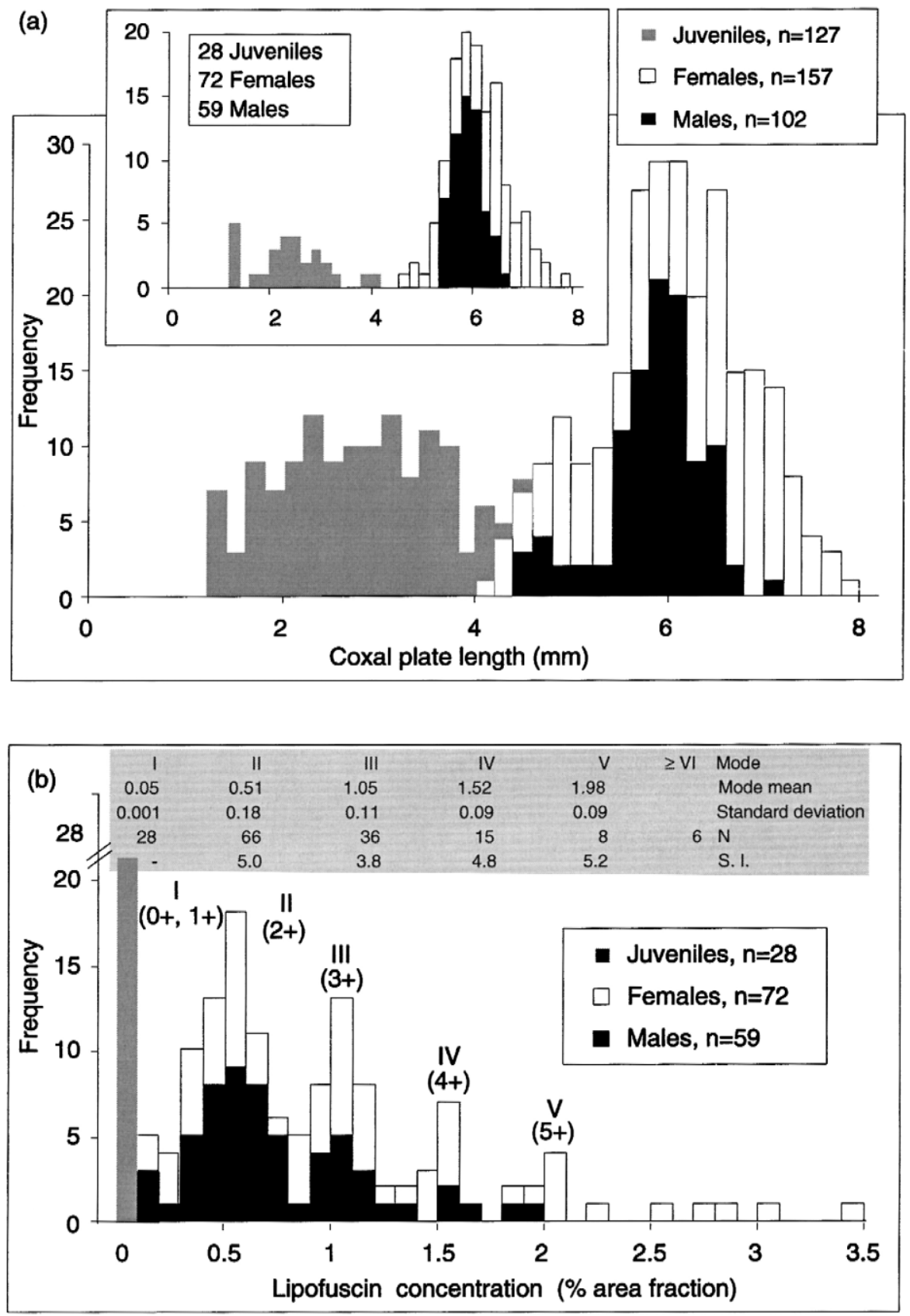

Fig. 4. W. obesa from the eastern Weddell Sea. (a) Coxal plate length-frequency distribution of 386 trap-caught individuals (inlay: 159 lipofuscin-analysed specimens), (b) lipofuscin concentration-frequency distribution including results from modal progression analysis. The frequency $(n)$ of one bar is $n_{\text {total }}$ bar $=n_{\text {females }}+n_{\text {males }}+n_{\text {juveniles }} . N=$ number of individuals per mode, S.I. $=$ Separation index, roman numerals $=$ modes, arabic numerals $=$ cohort designation in years $+($ see text $)$. 

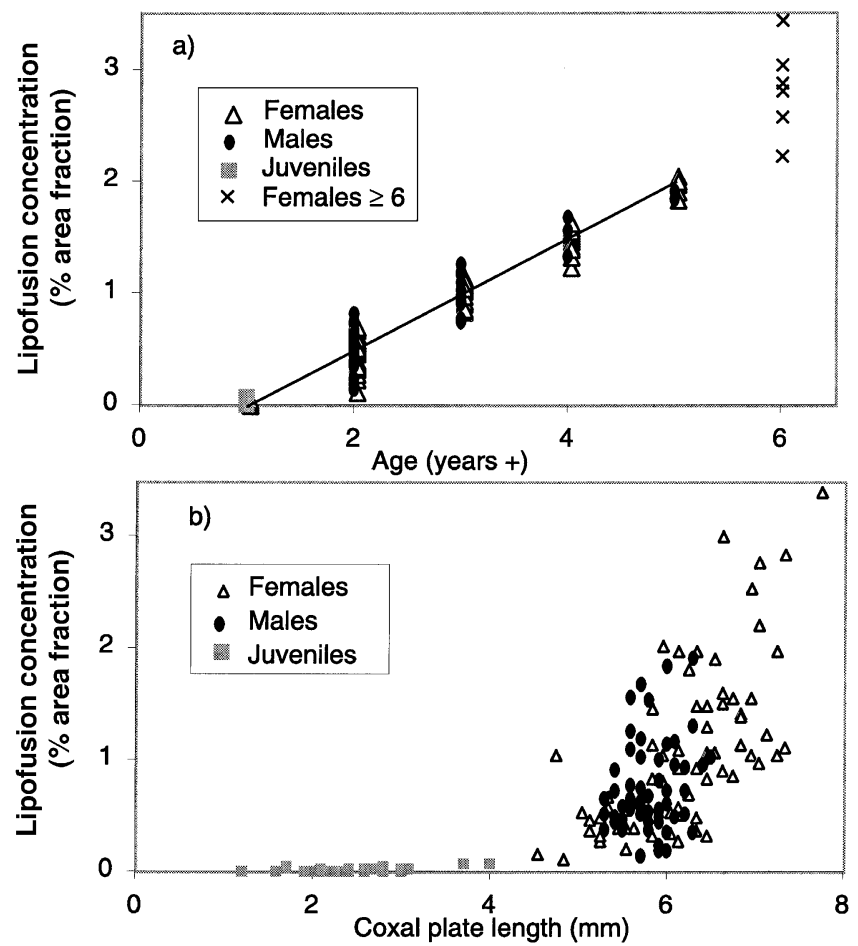

Fig. 5. W. obesa from the eastern Weddell Sea. Lipofuscin concentration in relation to (a) lipofuscin-based estimated age $\left(\mathrm{AF}=0.49 \times \mathrm{age}+0.49, r^{2}=0.95, p<0.001 ; \mathrm{AF}=\right.$ lipofuscin concentration $)$, and (b) body size.

right after larval release (in decapods: Sheehy, 1990a,c; Sheehy et al., 1995). Chapelle (1991) observed seven juvenile instars in $W$. obesa with moulting frequencies of $\geq 4$ months (Chapelle, personal communication) and an average increase in size of $0.4 \mathrm{~mm}$ $L_{\text {cox }} /$ moult. Thus, a newly hatched $1.2 \mathrm{~mm} L_{\text {cox }}$ sized individual could, after a year, have reached at max. $2.4 \mathrm{~mm} L_{\mathrm{cox}}$. The fit of the VBGF growth curves resulted in:

$L_{a}=7.47\left(1-\mathrm{e}^{-0.50(a+0.46)}\right), r^{2}=0.89, n=100$ (females and juveniles, Fig. 6a) (standard errors: $L_{\infty}=0.35, k=0.07, a_{0}=0.08$ );

$L_{a}=6.92\left(1-\mathrm{e}^{-0.60(a+0.42)}\right), r^{2}=0.87, n=87$ (males and juveniles, Fig. 6b) (standard errors: $L_{\infty}=0.36, k=0.09, a_{0}=0.07$ ).

The Gompertz growth curves estimated:

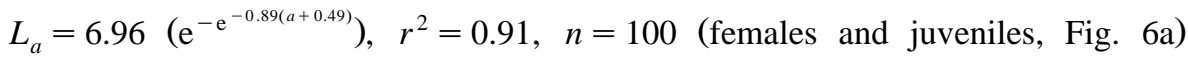
(standard errors: $L_{\infty}=0.19, k=0.08, a_{0}=0.06$ );

$L_{a}=6.55\left(\mathrm{e}^{-\mathrm{e}^{-1.02(a+0.39)}}\right), r^{2}=0.89, n=87$ (males and juveniles, Fig. 6b) (standard errors: $\left.L_{\infty}=0.21, k=0.09, a_{0}=0.06\right)$. 
(a) females and juveniles, $n=100$

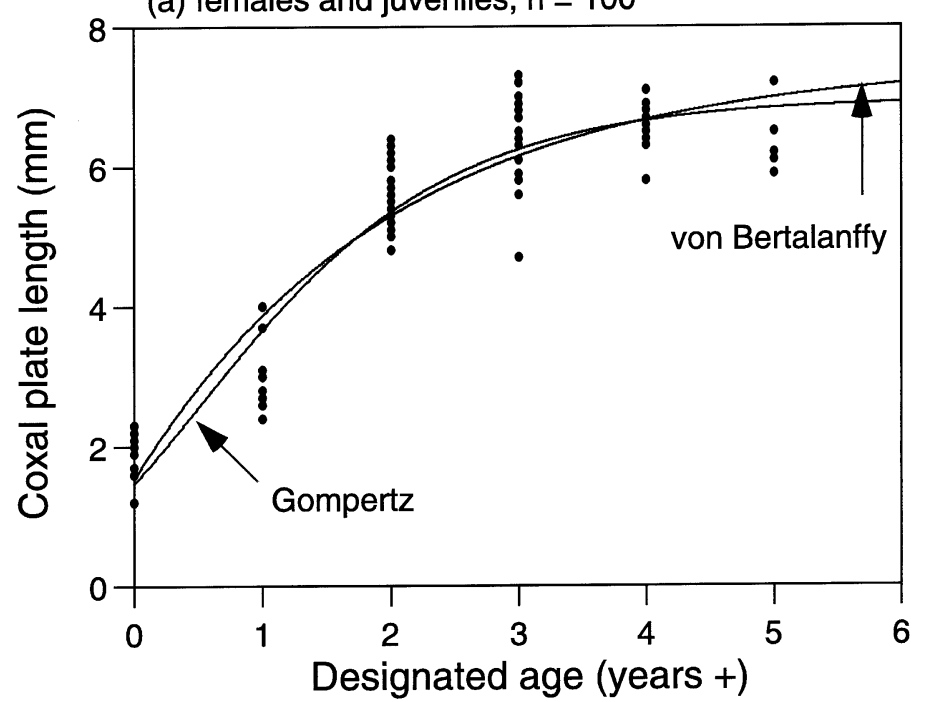

(b) males and juveniles, $n=87$

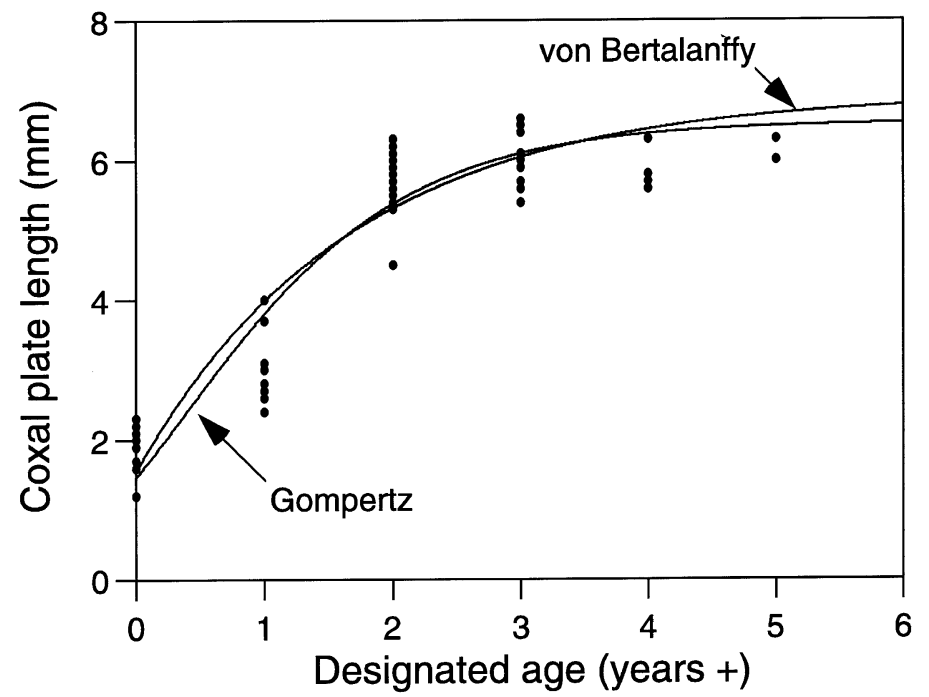

Fig. 6. W. obesa from the eastern Weddell Sea. Growth curves fitted to size at lipofuscin-estimated age data in (a) females and (b) males. Von Bertalanffy: $L_{\text {cox } \infty}=7.47 \mathrm{~mm}, k=0.50$ per year, $a_{0}=-0.49$ years, $r^{2}=0.89$ (females), $L_{\text {cox } \infty}=6.92 \mathrm{~mm}, k=0.60$ per year, $a_{0}=-0.42$ years, $r^{2}=0.87$ (males); Gompertz: $L_{\operatorname{cox} \infty}=$ $6.96 \mathrm{~mm}, k=0.89$ per year, $a_{0}=-0.49$ years, $r^{2}=0.91$ (females), $L_{\text {cox } \infty}=6.55 \mathrm{~mm}, k=1.02$ per year, $a_{0}=-0.39$ years, $r^{2}=0.89$ (males).

\subsection{Mortality and productivity}

Mortality $Z$, estimated from the catch curve, amounted to 0.27 per year for females and 0.43 per year for males (Fig. 7). Data from juveniles were not included in the 


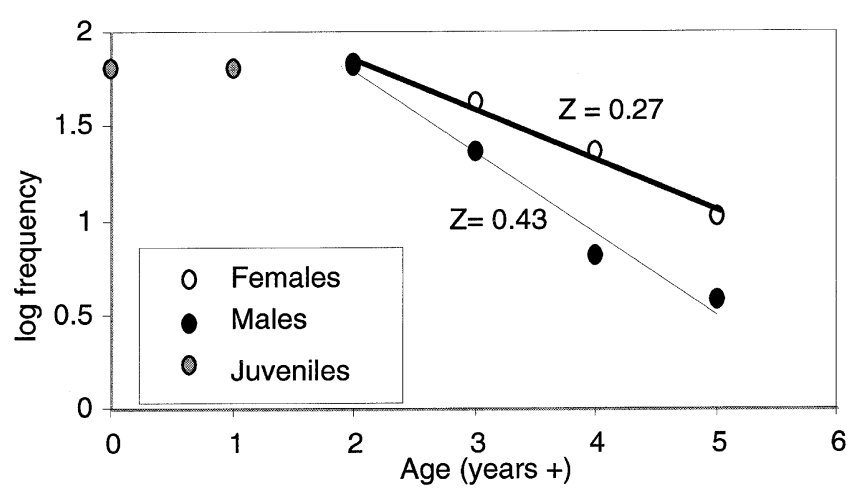

Fig. 7. Catch curve of W. obesa from the eastern Weddell Sea. Females: In $\left(n_{\text {age class }}\right)=2.40-0.27 \times$ age, $r^{2}=0.98$; males: In $\left(n_{\text {age class }}\right)=2.65-0.43 \times$ age, $r^{2}=0.98$. The number of individuals per age class $\left(n_{\text {age }}\right.$ class) was adjusted from lipofuscin-analysed subsample to total sample size (see text).

regression (according to Ricker, 1979; Pauly, 1984). The $P / B$ ratio calculated by the MSGRM was 0.25 per year (VBGF) and 0.26 per year (Gompertz) in females, and 0.31 per year (VBGF) and 0.32 per year (Gompertz) in males. The $P / B$ ratio estimates for juveniles was 2.26 per year (VBGF) and 2.20 per year (Gompertz), while the ratio for pooled data was 0.38 per year (VBGF) and 0.39 per year (Gompertz), respectively.

\section{Discussion}

\subsection{Lipofuscin characteristics}

According to Sohal and Wolfe (1986) lipofuscin granules are "membrane-bound lysosomal organelles, which contain lipoidal moieties, exhibit yellow to brown coloration, emit yellow to greenish fluorescence under UV, and accumulate in the cytoplasm progressively with age under normal physiological conditions". Additionally, they usually react positively to Sudan Black staining (for W. obesa see Bluhm et al., in press) and to Periodic-acid-Schiff and other histochemical reactions, but exhibit variable responses to these (Brunk et al., 1992). Autofluorescence, thus, remains the most useful feature for histological localization and quantification in crustaceans (Medina et al., 2000). Our observations (Bluhm et al., in press, this study) coincide well with the morphological and microscopical characteristics described for Decapoda (Sheehy, 1989; Sheehy et al., 1996; Medina et al., 2000; Vila et al., 2000); histochemical tests apart from Sudan staining, however, were not undertaken. Ultrastructurally, granules correspond with the four categories summarized in Terman and Brunk (1998), granular, homogeneous, lamellated and compound, the latter being most common. In contrast to decapods, in which the pigment is especially dense in cells of the posterior lateral somacluster of the olfactory lobe (Sheehy, 1989, 1990b; Sheehy et al., 1995, 1998; Bluhm et al., in press), the lipofuscin granules in W. obesa concentrated in the transition zones described above. Whether the respective cells are more active than other so- 
macluster cells or neuropil cells, or whatever else may be the reason for this phenomenon, remains unanswered. The practical consequence is that relative lipofuscin concentrations as areal pigment proportion of the studied brain region cannot be compared between $W$. obesa and decapods. Irrespective of this, the concentration increased with age as it did in decapod species (e.g. Belchier et al., 1998; Sheehy et al., 1999; Vila et al., 2000; Bluhm and Brey, in press).

\subsection{Trap effects}

Unbiased size-frequency distributions of scavenging amphipods are notoriously difficult to obtain with baited traps, as these are often selective (Thurston, 1979; Slattery and Oliver, 1986). No ovigerous females of $W$. obesa appeared in our traps; in other studies, this phenomenon was interpreted as female avoidance behaviour so as to reduce the probability of being preyed upon (Slattery and Oliver, 1986; Moore, 1994). Thurston (1979) suggests that a corollary of the highly extendable gut in obligate necrophages is the inability of females to feed and brood at the same time, as they would lose their broods if the gut were greatly extended. On the other hand, our sampling period (January-February) was after females probably had released their young, as hatchling release was reported to begin in early October at the Antarctic Peninsula (Chapelle, 1991). If this were true as well for the Weddell Sea population, few ovigerous females would be left to be caught. However, we found relatively few juveniles, which might be explained by a different mode of feeding, as suggested by Chapelle (1991) and Klages (1991) for sub-Antarctic, as well as high-Antarctic W. obesa. The smallest juveniles we caught may, therefore, have been released in the traps rather than having been attracted there by bait. Hence, we assume that our LFD may be reasonably representative above ca. $4 \mathrm{~mm} L_{\text {cox }}$, but is not in juveniles. Parameters derived from the LFD should be interpreted with care.

\subsection{Size vs. lipofuscin}

Length-frequency distributions have been used successfully to separate cohorts in low latitude amphipod species (e.g. Collie, 1985; Moore and Wong, 1996) and even in some Arctic species (Beuchel, 2000; Poltermann, 2000), although age validation was lacking in the latter. The LFD obtained for W. obesa, in contrast, shows a juvenile mode and one large peak in larger size classes in which individual cohorts cannot be distinguished (Fig. 4a), as is often observed is slow-growing invertebrates (Bannister et al., 1994; Brey et al., 1995; Bluhm et al., 1998; Bluhm and Brey, in press). Aquaria observations demonstrated that adult $W$. obesa can be maintained for years without much obvious growth increment (personal unpublished observation), thus indicating that the large peak in the LFD may be caused by a pile up of many age classes (Fig. 8). Applying very high-resolution size measurements, Chapelle (1991) separated 13 instars in $W$. obesa, though without a precise time axis. Slow growth combined with nonmoulting females during breeding, interference of moulting stages with cohorts and potential effects of parasites, injuries and starvation on growth can lead to remarkable size-at-age variability obscuring age groups in LFD (Fig. 5, Ikeda and Dixon, 1982; Somers and 


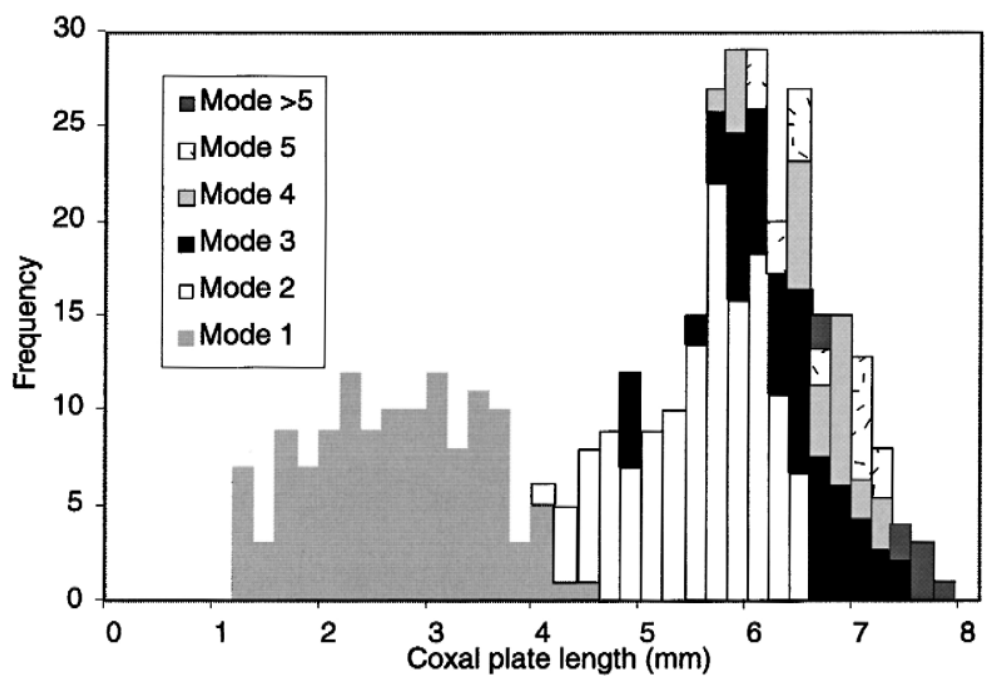

Fig. 8. W. obesa from the eastern Weddell Sea. Distribution of modes derived from the modal progression analysis of the lipofuscin concentration-frequency histogram in the length-frequency distribution histogram. The number of individuals per age group was adjusted from lipofuscin-analysed subsample to total sample size (see text). Frequency total bar $=n_{\text {mode } 1}+n_{\text {mode } 2}+\ldots+n_{\text {mode }}>5$.

Kirkwood, 1991). Size can, therefore, be an inadequate age predictor in slow-growing amphipods as was demonstrated for decapods (Belchier et al., 1994, 1998; Sheehy et al., 1998, 1999).

The lipofuscin concentration-frequency distribution, although uncorrected for potential trap effects (see above) shows the characteristic feature of synchronously reproducing populations, i.e. distinct age groups. Our findings support Chapelle's conclusion (1991) that W. obesa reproduces seasonally. In scavenging invertebrates, both continuous reproduction (e.g. Stockton, 1982; Ingram and Hessler, 1987; McKillup and McKillup, 1997) and seasonal reproduction (e.g. Rakusa-Suszeszewski, 1982; Moore and Wong, 1996) occur in deep-as well as shallow-water habitats including Antarctic locations. Chapelle's and Klages' presumptions (both 1991) of a nonscavenging feeding mode in juvenile $W$. obesa may explain seasonal coupling of juvenile release to the onset of near-surface primary production and subsequent sedimentation. Hessler et al. (1978) reported indications that deep-sea scavenging amphipods gradually shift from bacterial and sediment-feeding mode to scavenging. Three factors, seasonal reproduction, linear lipofuscin accumulation reflected in regular spacing of peaks, and validation studies on a number of crustacean species (Sheehy et al., 1994, 1996, 1998; Wahle et al., 1996; Belchier et al., 1998) provide strong evidence that peaks in the LCFD reflect age groups.

\subsection{Growth and longevity}

Growth in W. obesa and other polar amphipods is slow (Bone, 1972; Poltermann, 2000) compared with boreal and tropical species (Venables, 1981). In contrast, the 
overall growth performance, measured by the index $\psi$ (Brey, 1999a), seems to be slightly higher latitudes as shown by an auximetric grid (according to Pauly, 1979, 1984, Fig. 9). The index $\psi$ is calculated by maximum body mass and the time in which it is reached, i.e. maximum age (Brey, 1999a). According to lipofuscin analysis, W. obesa reaches an age of $>5$ years, presumably up to 8 years in females. Greater age in females is reflected in sex ratio favouring females $(1.5: 1)$ and higher maximum body size (Chapelle, 1991). Our estimate agrees with Chapelle's rough calculations (1991, personal communication) from laboratory observations when multiplying an average moulting frequency of 4 to 11 months by 13 instars. Life span in gammaridean amphipods ranges from only a few months (e.g. Gammarus mucronatus, LaFrance and Ruber, 1985; Talorchestia margaritae, Venables, 1981) to apparently over 10 years (Eurythenes gryllus, Ingram and Hessler, 1987) (reviewed in Saint-Marie, 1991). Littoral amphipods are typically multivoltine with generation times of 0.5 to 1.5 years (annual) or $<0.5$ years (semiannual) in which two or more generations are produced per year (Wildish and Peer, 1981). Sublittoral species, in contrast, have either annual or biannual life histories and produce a single or few broods in their lifetimes. Our findings correspond to Sainte-Marie's results (1991) of his review of 302 populations of gammaridean amphipods, demonstrating that mean life span was significantly longer in (i) cold-rather than in warm-living populations, (ii) in Lysianassoidea and Eusiroidea compared with other superfamilies, and (iii) supposedly in deep-living compared to shallow-living species. Investigations on species from high latitudes are still scarce, but

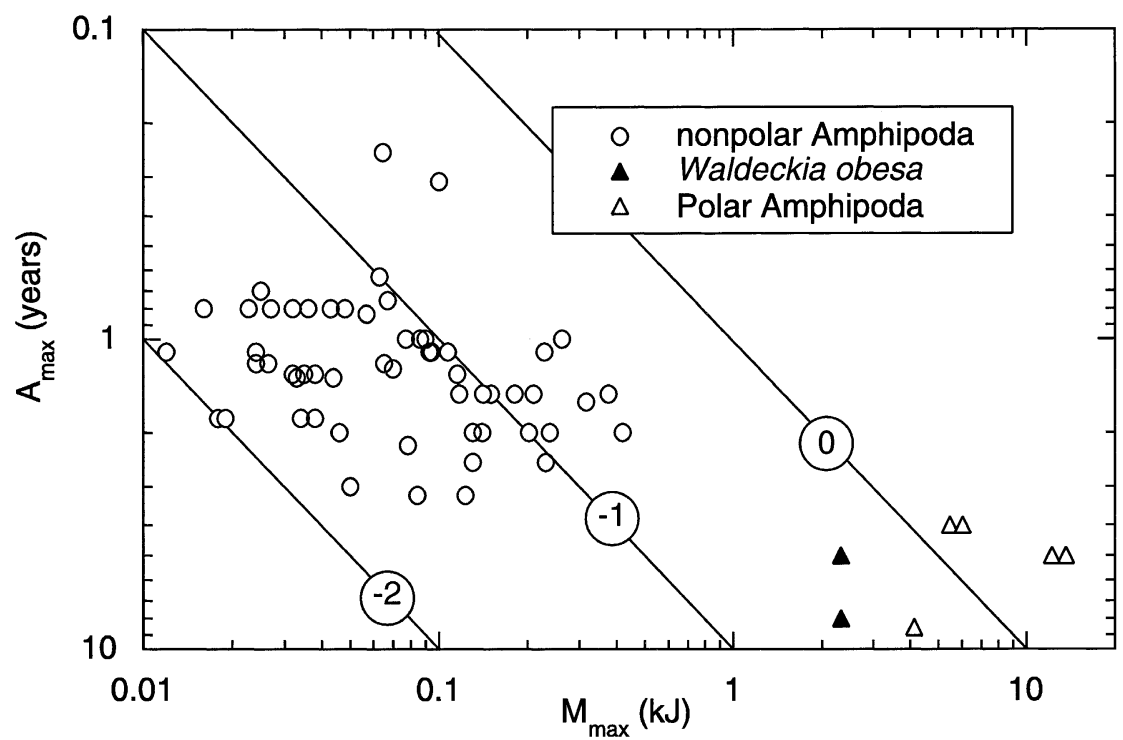

Fig. 9. Auximetric grid comparing overall growth performance $\psi$ ( $=\log$ (maximum body weight $/$ maximum age) of polar and nonpolar Amphipoda. Diagonal lines mark equal values of $\psi$ ( = numbers in circles). Polar Amphipoda: Bovallia gigantea (Thurston, 1968, 1970; Bone, 1972), Gammarus wilkitzkii (Poltermann, 2000). Data collection: Brey (1995, 1999b). 
show a tendency towards life spans exceeding 2 years (Thurston, 1968, 1970; Bone, 1972; Highsmith and Coyle, 1992; Klages, 1993; Beuchel, 2000; Poltermann, 2000, this study) combined with delayed maturity, comparatively large embryos and semelparity. If reaching maturity at an age of $2+$ years and reproducing annually, female $W$. obesa could reproduce at least four times during their lifetimes. Based on an estimate of 25 eggs/female and brood (incidential observation by Chapelle, 1991), lifetime potential fecundity (125 to 200 embryos (E)) and reproductive potential (25 E/female and year) are within the range given for Lysianassidae by Sainte-Marie (1991) (1 to 215 E, mean $=82$, and 1 to $92 \mathrm{E} /$ female and year, mean $=43$, respectively). Generally, delayed maturity, high longevity and slow ageing in polar invertebrates are explained by limited food availability and low metabolism (Clarke and North, 1991; Brey and Clarke, 1993; Thiel et al., 1996). Very low $\mathrm{O}_{2}$-consumption values were indeed measured for $W$. obesa (Chapelle and Peck, 1995) and match the low activity typically observed in this species (personal communication, Chapelle; personal observation). Only after feeding does oxygen consumption rise by a factor of 4 to 7 (Chapelle and Peck, 1995). Higher longevity compared to their lower latitude congeners is also known from other Antarctic crustaceans, e.g. Euphausiacea (Siegel, 1987), Mysidacea (Ward, 1984; Siegel and Mühlenhardt-Siegel, 1988), Isopoda (Luxmore, 1982) and Decapoda (Gorny et al., 1993; Bluhm and Brey, in press).

\subsection{Productivity and mortality}

Published $P / B$ ratios in amphipods range from 0.4 to 61 per year. In $W$. obesa and other Antarctic and Arctic amphipods the ratio is lower (0.38 to 1 per year; Thurston, 1970; Bone, 1972; Highsmith and Coyle, 1990, 1992; Poltermann, 2000; this study) than in lower latitude species in which it mostly varies between 2 and 7 per year. Very high $P / B$ of over 30 per year known from very small, short-lived, (sub)-tropical Gammaridae and Hyalellidae (Fredette and Diaz, 1986a,b; Venables, 1981). Despite low turnover rates in polar amphipods, production can still be remarkably high if the biomass is high accordingly, as found in Ampelisca macrocephala, A. birulai and Byblis spp. in the Bering Sea (Highsmith and Coyle, 1990, 1992). For Antarctic amphipods, however, Gerdes et al. (1992) published comparatively low biomass values, while Jarre-Teichmann et al. (1997) conclude from their Weddell Sea model that values may be markedly underestimated. Data on biomass and abundance of W. obesa are, unfortunately, not available. In terms of the growth-mortality continuum of benthic invertebrates introduced by Brey and Gage (1997), the relation between $Z$ and $k$ is comparatively high in W. obesa, indicating above-average predation pressure. Antarctic amphipods are indeed known to be an important food source for fish (Olaso et al., 2000), ophiuroids (Jarre-Teichmann et al., 1997) and crustaceans (Storch et al., in press). Amphipods in the Weddell Sea, in general, and scavengers, in particular, may, therefore, represent an important link in the energy transfer to higher trophic levels and as energy recyclers of carrion. Comparable control positions were described for Bering Sea amphipods providing the link from sedimenting primary production to grey whales (Highsmith and Coyle, 1992), and for Arctic sympagic amphipods representing a substantial element in cryopelagic coupling (Poltermann, 1997; Werner, 1997). 
To conclude:

- modal progression analysis of LCFD of W. obesa allows separation of modes, which presumably reflect age classes;

- W. obesa is a "typical high-latitude invertebrate" characterized by high longevity and low productivity;

- the Antarctic scavenging amphipod community may be an important energy mediator from carrion to high trophic levels;

- adequate sampling techniques for scavenging species are urgently needed to obtain reliable data on abundance, biomass, as well as size and weight frequencies.

\section{Acknowledgements}

The help of the "Polarstern" crew and the logistical support by W.E. Arntz are greatly acknowledged. Special thanks are due to C. de Broyer, Y. Scailleur and G. Chapelle for their cooperation regarding the amphipod trap catches. K. Beyer kindly produced the TEM micrographs; K. Premke, I. Falkner and K. Schwarzpaul helped sectioning tiny amphipod brains - thanks for your stamina. We are indebted to G. Chapelle for fruitful discussion and helpful information on $W$. obesa and to two anonymous referees for their constructive comments on the manuscript. This project was financed by the German Research Foundation DFG (Br 1220/4-1). [RW]

\section{References}

Allen, K.R., 1971. Relation between production and biomass. J. Fish. Res. Board Can. 28, 1573-1581.

Arnaud, P.M., Jazdzewski, K., Presler, P., Sicinski, J., 1986. Preliminary survey of benthic invertebrates collected by Polish Antarctic expeditions in Admirality Bay (King George Island, South Shetland Islands, Antarctica). Pol. Polar Res. 7, 7-24.

Arntz, W.E., Gutt, J., 1999. The expedition ANTARKTIS XV /3 (EASIZ II) of RV "Polarstern" in 1998. Ber. Polarforsch. 301, 1-229.

Arntz, W.E., Gutt, J., Klages, M., 1997. Antarctic marine biodiversity: an overview. In: Battaglia, B., Valencia, J., Walton, D.W.H. (Eds.), Antarctic Communities. Species, Structure and Survival. Cambridge Univ. Press, Cambridge, pp. 3-14.

Bannister, R.C.A., Addison, J.T., Lovewell, S.R.J., 1994. Growth, movement, recapture rate and survival of hatchery-reared lobsters Homarus gammarus (Linnaeus, 1758) released into the wild on the English east coast. Crustaceana 67 (2), 156-172.

Barnard, J.L., Karaman, G.S., 1991. The families and genera of marine gammaridean Amphipoda (except marine gammaroids). Rec. Aust. Mus. $13(1+2), 1-866$, Suppl.

Belchier, M., Shelton, P.M.J., Chapman, C.J., 1994. The identification and measurement of fluorescent age-pigment abundance in the brain of a crustacean Nephrops norvegicus by confocal microscopy. Comp. Biochem. Physiol. 108B (2), 157-164.

Belchier, M., Edsman, L., Sheehy, M.R.J., Shelton, P.M.J., 1998. Estimating age and growth in long-lived temperate freshwater crayfish using lipofuscin. Freshwater Biol. 39, 439-446.

Beuchel, F., 2000. Population structure of the autochthonous sympagic amphipods Gammarus wilkitzkii and Apherusa glacialis in selected categories of sea ice. MSc thesis, Free University of Berlin and University Courses on Svalbard, pp. 86. 
Bhattacharya, C.G., 1967. A simple method of resolution of a distribution into Gaussian components. Biometrics 23, 115-135.

Bluhm, B.A., Brey, T. Age determination in the Antarctic shrimp Notocrangon antarcticus (Pfeffer, 1887) (Crustacea: Decapoda) using the autofluorescent pigment lipofuscin. Mar. Biol. (in press).

Bluhm, B.A., Piepenburg, D., v.Juterzenka, K., 1998. Distribution, standing stock, growth, mortality and production of Stronglyocentrotus pallidus (Echinodermata: Echinoidea) in the northern Barents Sea. Polar Biol. 20, 325-334.

Bluhm, B.A., Brey, T., Klages, M., Arntz, W.E., in press. Occurrence of the autofluorescent pigment lipofuscin in polar crustaceans and its potential as an age marker. Polar Biol.

Bone, D.G., 1972. Aspects of the Antarctic amphipod Bovallia gigantea Pfeffer at Signy Island, South Orkney Islands. Br. Antarct. Surv. Bull. 27, 105-122.

Brandt, A., Mühlenhardt-Siegel, U., Siegel, V., 1998. An account of the Mysidacea (Crustacea, Malacostraca) of the Antarctic and Subantarctic Ocean. Antarct. Sci. 10 (1), 3-11.

Brey, T., 1995. Empirische Untersuchungen zur Populationsdynamik makrobenthischer Evertebraten. Habilitationsschrift. University of Bremen, Bremen, 169.

Brey, T., 1999a. Growth performance and mortality in aquatic macrobenthic invertebrates. Adv. Mar. Biol. 35, 153-223.

Brey, T., 1999b. A collection of empirical relations for use in ecology modelling. Naga, ICLARM Q. 22 (3), 24-28.

Brey, T., Clarke, A., 1993. Population dynamics of marine benthic invertebrates in Antarctic and Subantarctic environments: are there unique adaptations? Antarct. Sci. 5 (3), 253-266.

Brey, T., Gage, J.D., 1997. Interactions of growth and mortality in benthic invertebrate populations: empirical evidence for a mortality-growth continuum. Arch. Fish. Mar. Res. 45 (1), 45-59.

Brey, T., Pearse, J., Basch, L., McClintock, J., 1995. Growth and production of Sterechinus neumayeri (Echinoidea: Echinodermata) in McMurdo Sound, Antarctica. Mar. Biol. 124, 279-292.

Brunk, U.T., Marzabadi, M.R., Jones, C.B., 1992. Lipofuscin, lysosomes, and iron. In: Lauffer, R.B. (Ed.), Iron and Human Disease. CRC Press, Boca Raton, FL, pp. 237-260.

Chapelle, G., 1991. Cycle de dévelopment et "saisonalité" de la reproduction de Waldeckia obesa, Chevreux, amphipode nécrophage antarctique. MSc thesis, Université Catholique de Louvain, Bruxelles, pp. 94.

Chapelle, G., 1995. Estimating size of amphipods in life cycle studies: what to measure and what for? Pol. Arch. Hydrobiol. 42 (4), 295-302.

Chapelle, G., Peck, L.S., 1995. The influence of acclimation and substratum on the metabolism of the Antarctic amphipods Waldeckia obesa (Chevreux 1905) and Bovallia gigantea (Pfeffer 1888). Polar Biol. $15,225-232$.

Christiansen, B., 1996. Bait-attending amphipods in the deep sea: a comparison of three localities in the north-eastern Atlantic. J. Mar. Biol. Assoc. U. K. 76, 345-360.

Christiansen, B., Pfannkuche, O., Thiel, H., 1990. Vertical distribution and population structure of the necrophagous amphipod Eurythenes gryllus in the West European Basin. Mar. Ecol. Prog. Ser. 66, 35-45.

Clarke, A., North, A.W., 1991. Is the growh of polar fish limited by temperature? In: DiPrisco, G., Maresca, B., Tota, B. (Eds.), 2nd Int. Ravello Conf.: The Biology of Antarctic Fishes, Ravello 1990. IIGB Press, Naples, pp. 54-69.

Collie, J.S., 1985. Life history and production of three amphipod species on Georges Bank. Mar. Ecol.: Prog. Ser. 22, 229-238.

Crisp, D.J., 1984. Energy flow measurements. In: Holme, N.A., McIntyre, A.D. (Eds.), Methods for the Study of Marine Benthos. Blackwell, London, pp. 284-372.

De Broyer, C., Jazdzewski, K., 1993. A checklist of the Amphipoda Crustacea of the Southern Ocean. Doc. Trav. L'l. R. Sc. N. B. 73, 1-154.

De Broyer, C., Jazdzewski, K., 1996. Biodiversity of the Southern Ocean: towards a new synthesis for the Amphipoda Crustacea. Boll. Mus. Civ. St. Nat. Verona 20, 547-568.

Fahrbach, E., Rohardt, G., Krause, G., 1992. The Antarctic coastal current in the southeastern Weddell Sea. Polar Biol. 12, 171-182.

France, R., Holmes, J., Lynch, A., 1991. Use of size-frequency data to estimate the age consumption of crayfish populations. Can. J. Fish. Aquat. Sci. 48, 2324-2332. 
Fredette, T.J., Diaz, R.J., 1986a. Life history of Gammarus mucronatus Say Amphipoda: Gammaridae in warm temperate estuarine habitats, York River, Virginia. J. Crustacean Biol. 6, 57-78.

Fredette, T.J., Diaz, R.J., 1986b. Secondary production of Gammarus mucronatus Say Amphipoda: Gammaridae in warm temperate estuarine habitats, York River, Virginia. J. Crustacean Biol. 6, 729-741.

Gayanilo Jr., F.C., Sparre, P., Pauly, P., 1996. FAO-ICLARM stock assessment tools (FISAT). Comput. Inf. Ser.-Fisheries. ICLARM/FAO, Rome, User's manual, pp. 126.

Gerdes, D., Klages, M., Arntz, W.E., Herman, R.L., Galéron, J., Hain, S., 1992. Quantitative investigations on macrobenthos communities of the southeastern Weddell Sea shelf based on multibox corer samples. Polar. Biol. 12, 291-301.

Gorny, M., Brey, T., Arntz, W., Bruns, T., 1993. Growth, development and productivity of Chorismus antarcticus Pfeffer (Crustacea: Decapoda: Natantia) in the eastern Weddell Sea, Antarctica. J. Exp. Mar. Biol. Ecol. 174, 261-275.

Hargrave, B.T., 1985. Feeding rates of abyssal scavenging amphipods (Eurythenes gryllus) determined in situ by time-lapse photography. Deep-Sea Res. 32 (4), 443-450.

Hargrave, B.T., Phillips, G.A., Prouse, N.J., Cranford, P.J., 1995. Rapid digestion and assimilation of bait by the deep-sea amphipod Eurythenes gryllus. Deep-Sea Res., Part I 42 (11/12), 1905-1921.

Hasselblad, V., 1966. Estimation of parameters for a mixture of normal distributions. Technometrics 8 (3), 431-444.

Hellmer, H.H., Bersch, M., 1985. The Southern Ocean. A survey of oceanographic and marine meteorological research work. Ber. Polarforsch. 26, 1-115.

Hessler, R.R., Ingram, C.L., Yayanos, A.A., Burnett, B.R., 1978. Scavenging amphipods from the floor of the Philippine Trench. Deep-Sea Res. 25, 1029-1047.

Highsmith, R.C., Coyle, K.O., 1990. High productivity of northern Bering Sea benthic amphipods. Nature 344, $862-864$.

Highsmith, R.C., Coyle, K.O., 1992. Productivity of arctic amphipods relative to gray whale energy requirements. Mar. Ecol.: Prog. Ser. 83, 141-150.

Ikeda, T., Dixon, P., 1982. Body shrinkage as a possible over-wintering mechanism of the Antarctic krill, Euphausia superba Dana. J. Exp. Mar. Biol. Ecol. 62, 143-151.

Ingram, C.L., Hessler, R.R., 1983. Distribution and behavior of scavenging amphipods from the central North Pacific. Deep-Sea Res. 30, 683-706.

Ingram, C.L., Hessler, R.R., 1987. Population biology of the deep-sea amphipod Eurythenes gryllus: inferences from instar analyses. Deep-Sea Res. 34 (12), 1889-1910.

Jarre-Teichmann, A., Brey, T., Bathmann, U.V., Dahm, C., Dieckmann, G.S., Gorny, M., Klages, M., Pages, F., Ploetz, J., Schnack-Schiel, S., Stiller, M., Arntz, W.E., 1997. Trophic flows in the benthic shelf community of the eastern Weddell Sea, Antarctica. In: Battaglia, B., Valencia, J., Walton, D.W.H. (Eds.), Antarctic Communities: Species, Structure and Survival. Univ. Press, Cambridge, pp. 118-134.

Klages, M., 1991. Biologische und populations dynamicsche Untersuchungen an ausgewählten Gammariden (Crustacea: Amphipoda) des südöstlichen Weddellmeeres, Antarktis. PhD thesis, University of Bremen, Bremen, pp. 240.

Klages, M., 1993. Distribution, reproduction and population dynamics of the Antarctic gammaridean amphipod Eusirus perdentatus Chevreux, 1912 (Crustacea). Antarct. Sci. 5 (4), 349-359.

LaFrance, K., Ruber, E., 1985. The life cycle and productivity of the amphipod Gammarus mucronatus on a northern Massachusetts salt marsh. Limnol. Oceanogr. 30, 1077-1967.

Luxmore, R.A., 1982. Moulting and growth in serolid isopods. J. Exp. Mar. Biol. Ecol. 56, 63-85.

MacPherson, B.R., Steele, V.J., 1980. Microanatomy of the central nervous system of Gammarus setosus Dementieva (Amphipoda). The supraoesophageal ganglion brain. Crustaceana 38 (2), 113-120.

Marquardt, D.W., 1963. An algorithm for least-square estimation of nonlinear parameters. J. Soc. Ind. Appl. Math. 11, 431-441.

McKillup, S.C., McKillup, R.V., 1997. Effect of food supplementation on the growth of a intertidal scavenger. Mar. Ecol.: Prog. Ser. 148, 109-114.

Medina, A., Vila, Y., Megina, C., Sobrino, I., Ramos, F., 2000. A histological study of the age-pigment, lipofuscin, in dendrobranchiate shrimp brains. J. Crustacean Biol. 20 (3), 423-430.

Mekhanikova, I., Chapelle, G., De Broyer, C. Results of a new sampling device in the deep part of Baikal 
Lake: description of Echiuropus bekmanae n.sp. Crustacea, Amphipoda, Gammaridae. Hydrobiologia, submitted for publication.

Moore, P.G., 1994. Observations on the behaviour of the scavenging lysianassoid Orchomene zschaui (Crustacea: Amphipoda) from South Georgia South Atlantic. Mar. Ecol.: Prog. Ser. 113, 29-38.

Moore, P.G., Wong, Y.M., 1996. Observations on the life history of Orchomene nanus Kroyer Amphipoda: Lysianassoidea at Millport, Scotland as deduced from baited trapping. J. Exp. Mar. Biol. Ecol. 195, 53-70.

Mühlenhardt-Siegel, U., 1999. The biogeography of Cumacea. A comparison between South America, the Subantarctic islands, and Antarctica: present state of the art. Sci. Mar. 63 (Suppl. 1), 295-302.

Nagata, K., 1986. Amphipod crustaceans found near Syowa Station, Antarctica: Pt. 1. Mem. Nat. Inst. Polar Res. 40, 249-258.

Olaso, I., Rauschert, M., De Broyer, C., 2000. Trophic ecology of the family Artedidraconidae (Pisces: Osteichthyes) and its impact on the eastern Weddell Sea benthic system. Mar. Ecol.: Prog. Ser. 194, $143-158$.

Pauly, D., 1979. Gill size and temperature as governing factors in fish growth: a generalization of von Bertalanffy's growth formula. Ber. Inst. Meereskd. Kiel 63, 1-156.

Pauly, D., 1984. Fish population dynamics in tropical waters: a manual for use with programmable calculators. International Center for LivingAquatic Resources Management, Manila, Philippines. ICLARM Stud. Rev. Contribution No. 8 (143) 325.

Poltermann, M., 1997. Biologische und ökologische Untersuchungen zur kryopelagischen Amphipodenfauna des arktischen Meereises. Ber. Polarforsch. 225, 1-170.

Poltermann, M., 2000. Growth, production and productivity of the Arctic sympagic amphipod Gammarus wilkitzkii. Mar. Ecol.: Prog. Ser. 193, 109-116.

Porta, E.A., 1991. Advances in age pigment research. Arch. Gerontol. Geriatr. 212, 303-320.

Rakusa-Suszeszewski, S., 1982. The biology and metabolism of Orchomene plebs (Hurley, 1965) (Amphipoda: Gammaridea) from McMurdo Sound, Ross Sea, Artarctic. Mar. Biol. 1, 47-54.

Ricker, W.E., 1979. Growth rates and models. In: Hoar, W.S., Randall, D.J. (Eds.), Fish Physiol. vol. 8. Academic Press, New York, pp. 677-743.

Sainte-Marie, B., 1991. A review of the reproductive bionomics of aquatic gammaridean amphipods: variation of the life history traits with latitude, depth, salinity and superfamily. Hydrobiologia 223, 189-227.

Sheehy, M.R.J., 1989. Crustacean brain lipofuscin: an examination of the morphological pigment in the fresh-water crayfish Cherax cuspidatus Parastacidae. J. Crustacean Biol. 9 (3), 387-391.

Sheehy, M.R.J., 1990a. Potential of morphological lipofuscin age-pigment as an index of crustacean age. Mar. Biol. 107, 439-442.

Sheehy, M.R.J., 1990b. Widespread occurrence of fluorescent morphological lipofuscin in the crustacean brain. J. Crustacean Biol. 10 (4), 613-622.

Sheehy, M.R.J., 1990c. Individual variation in, and the effect of rearing temperature and body size on, the concentration of fluorescent morphological lipofuscin on the brains of freshwater crayfish, Cherax cuspitadus (Crustacea: Parastacidae). Comp. Biochem. Physiol. 96A (2), 281-286.

Sheehy, M.R.J., 1992. Lipofuscin age-pigment accumulation in the brains of ageing field- and laboratory-reared crayfish Cherax quadricarinatus von Martens (Decapoda: Parastacidae). J. Exp. Mar. Biol. Ecol. 161, $79-89$.

Sheehy, M.R.J., Wickins, J.F., 1994. Lipofuscin age pigment accumulation in the brain of the European lobster, Homarus gammarus L. Microsc. Anal. 40, 23-25.

Sheehy, M.R.J., Greenwood, J.G., Fielder, D.R., 1994. More accurate chronological age determination of crustaceans from field situations using the physiological age marker, lipofuscin. Mar. Biol. 121, 237-245.

Sheehy, M.R.J., Greenwood, J.G., Fielder, D.R., 1995. Lipofuscin as a record of "rate of living" in an aquatic poikilotherm. J. Gerontol. 50A (6), B327-B336.

Sheehy, M.R.J., Shelton, P.M.J., Wickins, J.F., Belchier, M., Gaten, E., 1996. Ageing the European lobster Homarus gammarus by the lipofuscin in its eyestalk ganglia. Mar. Ecol.: Prog. Ser. 143, 99-111.

Sheehy, M., Caputi, N., Chubb, C., Belchier, M., 1998. Use of lipofuscin for resolving cohorts of western rock lobster Panulirus cygnus. Can. J. Fish. Aquat. Sci. 55, 925-936.

Sheehy, M.R.J., Bannister, R.C.A., Wickins, J.F., Shelton, P.M.J., 1999. New perspective on the growth and longevity of the European lobster Homarus gammarus. Can. J. Fish. Aquat. Sci. 56, 1904-1915. 
Sheldahl, J.A., Tappel, A.L., 1974. Fluorescent products from aging Drosophila melanogaster: an indicator of free radical lipid peroxidation damage. Exp. Gerontol. 9, 33-41.

Siegel, V., 1987. Age and growth of Antarctic Euphausiacea (Crustacea) under natural conditions. Mar. Biol. 96, 483-495.

Siegel, V., Mühlenhardt-Siegel, U., 1988. On the occurrence and biology of some Antarctic Mysidacea (Crustacea). Polar Biol. 8, 181-190.

Slattery, P.N., Oliver, J.S., 1986. Scavenging and other feeding habits of lysianassid amphipods Orchomene spp. from McMurdo Sound, Antarctica. Polar Biol. 6, 171-177.

Smith, K.L., Baldwin, R.J., 1982. Scavenging deep-sea amphipods: effect of odor on oxygen consumption and a proposed metabolic strategy. Mar. Biol. 68, 287-298.

Sohal, R.S., Wolfe, L.S., 1986. Lipofuscin: characteristics and significance. In: Swaab, D.F., Fliers, E., Mirmiran, M., Van Gool, W.A., Van Haaren, F. (Eds.), Prog. Brain Res., vol. 70. Elsevier, Amsterdam, pp. 171-183.

Sokal, R.R., Rohlf, F.J., 1995. Biometry. W.H. Freeman, New York, 887.

Somers, I.F., Kirkwood, G.P., 1991. Population ecology of the grooved tiger prawn, Penaus semisulcatus, in the north-western Gulf of Carpentaria, Australia: growth, movement, age structure and infestation by the bopyrid parasite Epipenaeon ingens. Aust. J. Mar. Freshwater Res. 42, 349-367.

Stockton, W.L., 1982. Scavenging amphipods from under the Ross Ice Shelf, Antarctica. Deep-Sea Res. 29, 819-835.

Storch, V., Bluhm, B.A., Arntz, W.E., in press. Microscopic anatomy and ultrastructure of the digestive system of three Antarctic shrimps (Crustacea: Decapoda: Caridea). Polar Biol.

Terman, A., Brunk, U.T., 1998. Lipofuscin: mechanisms of formation and increase with age. APMIS 106, 265-276.

Thiel, H., Pörtner, H.O., Arntz, W.E., 1996. Marine life at low temperatures-a comparison of polar and deep-sea characteristics. In: Uiblein, F., Ott, J., Stachowitsch, M. (Eds.), Deep-sea and extreme shallowwater habitats: affinities and adaptations. Biosyst. Ecol. Ser., vol. 11, pp. 183-219.

Thurston, M.H., 1968. Notes on the life history of Bovallia gigantea Pfeffer (Crustacea, Amphipoda). Br. Antarc. Surv. Bull. 16, 57-64.

Thurston, M.H., 1970. Growth in Bovallia gigantea Pfeffer Crustacea: Amphipoda. In: Holdgate, M.W. (Ed.), Antarct. Ecol., vol. 1. Academic Press, London, pp. 269-278.

Thurston, M.H., 1979. Scavenging abyssal amphipods from the north-east Atlantic Ocean. Mar. Biol. 51, $55-68$.

Vader, W., 1972. Notes on Norwegian marine Amphipoda: 5. New records of Leptamphopus sarsii Calliopiidae. Sarsia 50, 22-28.

Venables, B.J., 1981. Aspects of the population biology of Venezuelan beach amphipod, Talorchestia margaritae (Talitridae), including estimates of biomass and daily production, and respiration rates. Crustaceana 41, 271-285.

Vila, Y., Medina, A., Megina, C., Ramos, F., Sobrino, I., 2000. Quantification of the age-pigment lipofuscin in brains of known-age, pond-reared prawns Penaeus japonicus Crustacea, Decapoda. J. Exp. Zool. 286, $120-130$.

Wahle, R.A., Tully, O., O’Donovan, V., 1996. Lipofuscin as an indicator of age in crustaceans: analysis of the pigment in the American lobster Homarus americanus. Mar. Ecol.: Prog. Ser. 138, 117-123.

Walker, A.O., 1907. Crustacea III. Amphipoda. National Antarctic Expedition 1901-1904. Natural History. Zoology and Botany 3, vol. 3. Royal Geographic Society, London, pp. 1-39.

Ward, P., 1984. Aspects of the biology of Antarctomysis maxima (Crustacea: Mysidacea). Polar Biol. 3, $85-92$.

Werner, I., 1997. Ecological studies on the Arctic under-ice habitat-colonization and processes at the ice-water interface. Ber. Sonderforschungsbereich 313 70, 1-67.

Wildish, D.J., Peer, D., 1981. Methods for estimating secondary products in marine Amphipoda. Can. J. Fish. Aquat. Sci. 38, 1019-1026. 